\title{
THE ECJ'S ERZBERGER RULING: A DOOR WIDELY OPENED TO NATIONAL MODELS OF EMPLOYEE PARTICIPATION?
}

\author{
Václav Šmejkal *
}

\begin{abstract}
In the recent decision of the Erzberger case C-566/15, the Court of Justice of the European Union had to address the issue of whether the national rules on employee participation in company management (so-called co-determination) are in line with EU law, in particular whether they do not restrict the free movement of workers within the EU internal market. Although in the present case the judges did not find the existence of restrictions, in their brief ruling they did not give answers to all the questions related to this case and the co-determination in multinational business groups. The article attempts to show for which cases of co-determination we already have clear answers in the current EU law and for which we do not. Overall, however, the analysis shows that the EU Court of Justice decision was pragmatic and therefore wise.
\end{abstract}

KEYWORDS: co-determination, EU internal market, free movement of workers, Erzberger vs. TUI, rights of employees

\section{INTRODUCTION}

The employee participation or more shortly co-determination is defined by the EU sources as ,a structure of decision-making within the enterprise whereby employees and their representatives exert influence on decisions, often at a senior level and at a relatively early stage of formulation." ${ }^{\text {It }}$ is therefore - in

\footnotetext{
Associate Professor of European law at the Faculty of Law, Charles University in Prague and Senior Lecturer in law at ŠKODA AUTO UNIVERSITY in Mladá Boleslav; smejkalv@ prf.cuni.cz

1 [https://www.eurofound.europa.eu/observatories/eurwork/industrial-relations-dictionary/ co-determination], entry made on March 11, 2007, accessed on 11/07/2018.
} 
practice - the right of employees to elect their representatives to the supervisory bodies of certain companies, usually those with more staff and the dualistic structure of management (i.e. with the executive and supervisory bodies). This right is regulated in a different way in most EU Member States ${ }^{2}$, but not directly by the uniform European Union harmonization legislation (although Article 153(1)f of the Treaty on the functioning of the EU (TFEU) allows for its minimum harmonization through EU directives adopted by unanimity in the Council). ${ }^{3}$ Only the related right of employees and their representatives to be informed and consulted by the employer is provided for in several EU secondary law acts. ${ }^{4}$

In this situation, the fundamental freedoms of movement within the EU's internal market may get into conflict with national models of co-determination. EU law holds that even the local legislation that is not subject to EU law harmonization cannot hinder the effectiveness of EU law in the areas where it operates and Member States thus cannot regulate matters that fall under their jurisdiction without respecting EU law. A concrete example of such a conflict affecting national co-determination rules was highlighted by the case of Konrad Erzberger v. TUI AG (C-566/15), decided by the Grand Chamber of the

\footnotetext{
2 According to different comparisons, certain participation rules exist in 17 EU Member States, but in not all of them employees can directly elect their representatives to company's governing bodies, they can for instance discuss strategic decisions and sometimes co-decide on them. See in Krause, R.: Acid Test ECJ. The EU Commission's opinion on the TUI CaseA critical commentary. Hans-Böckler-Stiftung No 23 Co-Determination Report August 2016. As typical countries of traditionally well-developed co-determination are considered Germany, Austria, the Netherlands and the Scandinavian states. See in Mulder, J.: The Law Concerning the Election of Employees' Representatives in Company Bodies. Report in light of he CJEU case Konrad Erzberger v TUI AG C-566/15. Hans-Böckler-Stiftung Co-Determination No. 29, 01.2017, s. 2-4, Keijzer, T., Oost, O., Van Ginneken, M.: The ECJ Erzberger Case: An Analysis of German Co-Determination and EU Law. European Company Law Journal Vol. 14, No. 6 (2017), p. 224.

3 Since April 2016, the European Trade Union Confederation (ETUC) has been pushing for its own proposal for a directive introducing an obligation to have a system of employee representation in the governing body in transnational companies. See ETUC position paper Orientation for a new EU framework on information, consultation and board-level representation rights (Part I), adopted at the extraordinary ETUC Executive Committee on 13 April 2016 in The Hague. [https://www.etuc.org/en/document/etuc-position-paperorientation-new-eu-framework-information-consultation-and-board-level] , accessed on 11/07/2018.

4 Directive 98/59/EC on collective redundancies, Directive 2001/23/EC on transfer of undertakings, Directive 2001/86/EC on consultation in European Company (Societas Europaea), Directive 2002/14/EC on information and consultation of employees, Directive 2003/72/EC on employee involvement in European Cooperative Society (SCE), Directive 2009/38/EC on European Works Councils.
} 
EU Court of Justice (CJEU) on July 18, 2017.5 A shareholder of TUI AG, a multinational company with headquarters in Germany, K. Erzberger, argued that there should be no employees' representatives in the supervisory board, because the German law under which they were elected was contrary to Article 18 TFEU (prohibition of discrimination) and Article 45 TFEU (free movement of workers). The alleged violation of EU rules consisted in the fact that TUI AG employees outside Germany ( $80 \%$ of all employees) could neither vote nor stand as candidates for the supervisory board and employees of TUI AG establishments in Germany, when transferred to work in TUI AG units in other Member States, lost their right to vote and to be elected.

In Germany, this case was, since its inception, considered to be a landmark one. Leftist forces and trade unions saw in it yet another neo-liberal attempt to further reduce the national model of social and employment rights. ${ }^{6} \mathrm{Com}-$ mentators agreed that a possible ruling on incompatibility of the German model of co-determination with EU law would create a precarious state of legal uncertainty as to whether the supervisory boards of hundreds of companies were lawfully constituted and whether their decisions were valid. The judgment handed down by the CJEU did not cause any such earthquake, however, the consequences of what the CJEU said, but also did not say, in the judgment are potentially far-reaching.

This is what the following analysis is about. It has been done with a certain time distance from the decision, and also with the knowledge of the comments that accompanied it. ${ }^{7}$ Its aim is therefore not to describe in detail the circumstances and content of the case but to answer the question whether we already have the necessary legal certainty that there is no conflict between national models of co-determination and the freedoms of the EU internal market, or under what conditions it is so.

\footnotetext{
5 CJEU C-566/15 Konrad Erzberger v. TUI AG, EU:C:2017:347.

6 See for instance Höpner, M. Weiss, M.: Co-determination Under Threat: Blocking Social Europe. Social Europe 12 January 2017, [https://www.socialeurope.eu/co-determination-threat-blocking-social-europe], accessed on 11/07/2018.

7 See for instance a thorough analysis made by Keijzer T., Oost, O., Van Ginneken, M.: The ECJ Erzberger Case: An Analysis of German Co-Determination and EU Law. European Company Law journal, Vol. 14, No. 6 (2017).
} 


\section{CROSS-BORDER CO-DETERMINATION AS A LAWFUL OPTION}

The preliminary question of the Berlin Higher Regional Court, which the CJEU had to deal with, asked whether: „Is it compatible with Article 18 TFEU... and Article 45 TFEU... for a Member State to grant the right to vote and to stand as a candidate for election as the workers' representatives in the supervisory body of a company only those workers who are employed in establishments of the company or in affiliated companies that are within the national territory?" (para 21).

Both the Advocate General (AG) Saugmandsgaard Øe in its Opinion (paras 5-11) and after him the Court (paras 3-9) considered necessary to clarify in detail what exactly the German law prohibits since there was not a single act containing an easily detectable ban. The fact that the Law on employee participation (Gesetz über die Mitbestimmung der Arbeitnehmer) from 1976 and the Law on industrial relations (Betriebsverfassungsgesetz) from 2001, do not allow the participation of employees employed by TUI in other Member States, does not follow directly from their provisions but has always been construed by German legal science on the basis of the principle of territoriality which prevents the extra-territorial enforcement of German law in other Member States. (AG para 18, CJEU para 14).

The principle according to which ,the competence of the German legislature is limited to German territory, which precludes employees employed in other Member States being included in the German employee participation system“" (AG para 88), was defended before the CJEU by the German and Austrian governments. Undoubtedly, it refers to a rule respected both by $\mathrm{EU}^{8}$ law and international law. ${ }^{9}$ It is evident that the German rules of co-determination would be difficult to enforce in case of a dispute in another Member State without its consent, which cannot be easily assumed if the co-determination is governed differently or is not regulated at all in that Member State. It would therefore appear that this objection of territoriality could end the whole dispute, because it is not possible to find in EU law any provision that would oblige the other 27 Member States to follow internally the laws of Germany.

\footnotetext{
8 CJEU rulings on territorial limits of applicability of national (tax) rules can be referred to here: C286/90 Poulsen a Diva Navigation, EU:C:1992:453, C-379/92 Peralta, EU:C:1994:296 and many others.

9 See for instance in Seidl-Hohenveldern, I. Mezinárodní právo veřejné (Public international law). 2. vydání, Praha: ASPI Publishing, 2001, marg. 1504-1517 - „The conflict with international law lies in the boldness of exercising its own state power in the territory of another state without its consent." (marg. 1506).
} 
This conclusion, however, is clear only at the level of abstract legal principles, because the existing practice has developed quite differently. Companies like Daimler or Volkswagen, also seated in Germany, allow their employees in other Member States to participate in the election of their representatives in their supervisory boards operating in German headquarters. ${ }^{10}$ The rules governing co-determination in Denmark, Sweden or Norway seem to have no problem with participation of "foreign" employees. ${ }^{11}$ The Advocate General himself stated in his Opinion that ,some Member States of the EU and the EEA actually grant employees employed in other Member States the right to vote and to stand in elections relating to the administrative and management bodies of national companies." (footnote 72).

An employee working for a "group“ seated in another Member State can enjoy the benefit of dual representation: according to the law of his country in the establishment located on its territory and according to the German law in the headquarters of the group on the territory of Germany. The recognition of extra rights to employees - enforceable in another jurisdiction - cannot be considered as a problem from the point of view of their home country. If German law provides that anyone, irrespective of his place of employment, has a certain right enforceable in Germany, it would not be an interference with the sovereignty of another State. ${ }^{12}$ For those reasons, perhaps surprisingly, the view of the German-Austrian jurisprudence on the restrictive effects of the principle of territoriality was not recognized as a relevant argument by the Advocate General (para 93) and ultimately also by the Court of Justice, which did not address at all the principle of territoriality in its judgment.

At this point, a generally valid partial conclusion can be made, that EU law does not preclude the national legislation of a Member State from allowing "foreign" employees of a company with a head office in the territory of that Member State to participate in a national system of co-determination. However, this conclusion is only a first step forward, because we still have no answer to the question of whether there is, besides this lawful option, also an obligation to allow such cross-border co-determination in order to avoid discrimination and restrictions on freedom of movement prohibited by EU law.

10 Keijzer, T., Oost, O., Van Ginneken, M.: op. cit. note 2, p. 217.

11 Mulder, J.: op. cit. note 2, p. 2.

12 See reasoning of the General Advocate in his Opinion in the Erzberger case, paras 95-96. EU:C:2017:347. 


\section{CROSS-BORDER CO-DETERMINATION AS A LEGAL OBLIGATION}

Probably everyone who wonders whether the representatives elected to the supervisory board by $20 \%$ of the employees from Germany would take into account the interests of those who elected them to the same extent as the interests of another $80 \%$ of their colleagues abroad, who did do not participate to their election, would feel that something does not fit here. Such system of co-determination creates a situation in which ,the interests of German employees are likely to be protected at the expense of their EU colleagues. ${ }^{\text {"13 }}$ From the perspective of employees of the same business group, even if they are scattered in places of employment in different EU countries, such a system may appear deeply unfair. The prevention of cross-border co-determination within a multinational business group logically appears to be fundamentally contrary to the principles underpinning the EU internal market: no national protectionism, no discrimination on the basis of country of origin.

Viewed by this optics, the original action brought by the shareholder, K. Erzberger, as well as the preliminary question of the Berlin Higher Regional Courtm, had their merits. Even the European Commission at first had no doubts about it as stated in its written opinion on the case:

"It is not compatible with Article 45 for a Member State to grant the right to vote and stand as a candidate for the employees' representatives in the supervisory board of a company only those workers who are employed in establishments of the company or in affiliated companies within the domestic territory if the Member State structures the co-determination right is such a way that it includes legal situations which, when viewed objectively, could be present both in the same Member State as well as also in another Member State. "14

Does compliance with EU law necessitate a Member State to allow a cross-border co-determination in its territory? The answer, summarized only in the conclusion that the Grand Chamber of the CJEU answered this question in the negative, is true but incomplete and fogging a few partial questions for which the answer is not so clear yet.

Keijzer, T., Oost, O., Van Ginneken, M.: op. cit. note 2, p. 221.

14 Quoted from Krause, R.: op. cit. note 2, p. 2. 


\section{APPLICATION OF ARTICLE 18 TFEU - PROHIBITION OF DISCRIMINATION}

A general prohibition of ,any discrimination on grounds of nationality“ laid down in Art 18 TFEU was mentioned both in the applicant's arguments and in the preliminary question to the CJEU. As highlighted above, in this case, the feeling that employees subject to the same strategic direction are treated differently seems evident. The Art. 18 also states, however, that the general prohibition of discrimination does not affect the specific provisions of the Treaties which apply the ban on discrimination in concreto.

On the basis of this restriction on the application of the general prohibition of discrimination, both the Advocate General and the CJEU quickly dealt with an analysis of the possible conflict of application of the German co-determination provisions with Article 18 TFEU:

"It is settled case-law that Article 18 TFEU is intended to apply independently only to situations governed by EU law in respect of which the Treaty lays down no specific prohibition of discrimination. As it is, in respect of freedom of movement for workers, the principle of non-discrimination is given specific effect by Article 45(2) TFEU. There would thus be no need for the Court to give a ruling with regard to Article 18 TFEU if Article 45 TFEU were applicable in the present case." (AG paras 39-40, CJEU paras 25-26).

The simple elegance of such an argument disappears if the subsequent analysis of a possible breach of Article 45 TFEU results in the conclusion that to those who might feel discriminated against by the established rules of co-determination - i.e. to the employees of a German business group employed outside Germany - the Article 45 TFEU does not apply at all. This Article of the Treaty protects employees who have exercised free movement, that is, they are seeking, exercising, or have been, for a certain period of time, performing dependent work outside the Member State of which they are nationals. This can hardly be the case if an employee, who has never left his home country, is only employed by an employer whose head office is located in another Member State. Under the settled case-law of the CJEU, the Treaty rules on the free movement of persons cannot be applied „to workers who have never exercised their freedom to move within the Union and who do not intend to do so". (CJEU para 28). Therefore, the TUI AG employees outside Germany are not fortunate twice: Article 18 TFEU, which they might want to invoke if they feel discriminated against, will not help them, as priority will be given, due to the cross-border situation of the case, to application of Article 45 TFEU. However, even this lex specialis does not offer them anything if their personal situation is found without an "EU element", i.e. without the exercise of free movement. 
At this point, apparently, more than one reader perceives that the CJEU got rid of the real problem using a purely formal argument. The Court should have ruled on the question whether, in a situation when the lex specialis is not applicable, it does not imply a return to the lex generalis, i.e. to the general prohibition of discrimination under Article 18 TFEU, as for instance Mulder argues. ${ }^{15}$ Similarly, K. Erzberger insisted before the CJEU that discrimination (within the meaning of Article 18 TFEU) takes place precisely in the case of foreign employees of companies with headquarters in Germany, whereas workers in Germany are, on the contrary, deprived of free movement (within the meaning of Article 45 TFEU). ${ }^{16}$ The prohibition of discrimination (in general) is standardly applied in EU law even where there is no element of movement of the allegedly discriminated individuals across the EU's internal borders ${ }^{17}$ - of course, except in cases where EU law cannot be applied at all - as it was the case right here, according to the CJEU.

Following such reasoning, another partial conclusion is very difficult to formulate. The CJEU sometimes finds the applicability of EU law where Member States do not expect it $^{18}$ and also applies the prohibition of discrimination and the restriction of free movement in cases where all participants are from one Member State and the "EU element" can only be assumed as potentially possible or otherwise distantly present. ${ }^{19} \mathrm{~A}$ firm point for understanding the CJEU decision in the Erzberger case may be found in the ad absurdum argument, i.e. by pointing to the absurdity of the outcome that the opposite solution would lead to. Finding the applicability of Article 45 TFEU to all employees of companies whose headquarters are located in another EU country would extend the status of EU migrant worker to tens of millions of staff who have never pulled their heels out of their native country. In Member States fully open to foreign investors, large numbers of the domestic population would suddenly be allowed to invoke the protection of EU migrants and the rights guaranteed to them and their family members (including those without EU citizenship) by EU law would be applied preferentially to the law of their home Member State.

\footnotetext{
15 Mulder, J.: op. cit. note 2, p. 6.

16 Hellwig, H.J.: German Corporate Co-determination of Emloyees and EU Law. University of Oxford, Faculty of Law Business Law Blog, 24 February 2017, [https://www.law.ox.ac.uk/ business-law-blog/blog/2017/02/german-corporate-co-determination-employees-and-eu-law] accessed on 11/07/2018.

17 For sure, if there is a discrimination case without a cross-border element, it is never based on nationality but on age, sex, religious or political affiliation etc.

18 Se for instance CJEU C617/10 Fransson, EU:C:2013:105.

19 This is a long series of cases, represented, for example, by an older decision CJEU C-14/83 Von Colson, EU:C:1984:153 and a newer decision C-144/04 Mangold, EU:C:2005:709 or C-108/09 Ker-Optika, EU:C:2010:725.
} 
The CJEU therefore decided pragmatically to exclude those employees from the protection of the rights conferred by Article 45 TFEU.

In spite of that positive assessment, we have no answer to the question of what would have been the solution if the plaintiff in the original case (that is, $\mathrm{K}$. Erzberger) and thereafter the Berlin Higher Regional Court formulating its preliminary question, referred only to an infringement of Article 18 TFEU, i.e. to a general prohibition of discrimination, and not to Article 45 TFEU at the same time. The Advocate-General and the CJEU would have to address the question of the applicability of EU law to non-migrant workers of a multinational enterprise group and could not have escaped it by giving priority to the analysis under Article 45 TFEU. The suggestion of their possible answer can be found in the fact that, although the preliminary question did not distinguish between the employees of subsidiaries and branches of the German company headquarters (it referred in general to 'establishments'), the Advocate General and the CJEU took advantage of the fact that TUI AG was in other Member States always present only through subsidiaries with their own legal personality (under the law of the host country), not through branches without their own legal personality. ${ }^{20}$ Employees of foreign subsidiaries of TUI AG, have been subject to the legal order of their home country in all aspects of their individual and collective employee rights, which of course implies that they have not been discriminated against on the ground of their nationality.

However, the CJEU by that narrowing of the scope of the preliminary question did not fully clarify whether its conclusion also applies to the cases of branches deriving their legal personality from the parent company and thus remaining subject in their internal rules (and sometimes through the labor law chosen) to the law of the Member State where the parent company is seated. The CJEU chairman, K. Lenaerts, raised at the oral hearing the question whether there was still no element of free movement of workers in the case of a branch of a foreign company, unlike the case of a local subsidiary whose employees did not actually carry out any free movement ${ }^{21}$. In the ruling, however, the CJEU did not address the issue - because it did not need to answer such question in the specific circumstances of the Erzberger case.

This does not mean, of course, that the question should not be answered for the future. The situation of an employee of a branch of a foreign legal person carrying out dependent work on the territory of his home country may be close to

\footnotetext{
20 In the Czech law for instance, even the entry of a branch operating on the Czech territory into the Business Register does not give to this branch its own legal personality. See the judgment of the Czech Supreme Administrative Court 9 Afs 289/2015 - 80 from February 11, 2016. 21 Hellwig, H.J.: op. cit. note 16.
} 
the situation of a "commuting worker" travelling to his employer each day to the other side of the border from his home country where he keeps his permanent residence. If a commuting employee is a migrant worker under EU law, it is entirely possible to ask under what conditions an employee of a branch of a foreign legal entity could and should be a migrant worker either. If he were to become a migrant EU worker, Article 45 TFEU would, of course, be applicable to him. The ad absurdum argument used above would not be appropriate here, because employees with this status would be in the order of magnitude much less numerous than employees of foreign companies' subsidiaries. There is no guarantee of a solution here, even after the decision on the Erzberger case.

\section{APPLICATION OF ARTICLE 45 - PROHIBITION OF OBSTACLES TO THE FREE MOVEMENT OF WORKERS}

If a larger group of employees who may feel affected by the impossibility of cross-border co-determination - i.e. "foreign" employees of a business group with headquarters in Germany - is completely out of the EU law scope of application, there remains only the analysis of the violation of Article 45 TFEU to the detriment of those potential or actual members of the supervisory board who might take, as an obstacle to their freedom of movement, the fact that they will have to give up their right if they receive a job offer in an establishment of the group outside of Germany.

In the present case, the issue thus was whether the TUI AG employees in Germany were restricted in their free movement by losing the benefit of co-determination and not whether the TUI AG employees outside Germany were harmed by the fact that they were in the supervisory board of the company represented only by delegates of the minority employed in Germany. It sounds like a paradox that EU law could be helpful to those who, by exercising the right of free movement, have been deprived of a certain "privilege" within the TUI group, while it cannot improve the situation of those who, being part of the same group, cannot achieve the same "privileged" status...

EU does indeed protect those workers who want to migrate and their own Member State relieves them of certain benefits, particularly in the social field, which they are entitled to. Almost exactly one year before the judgment in Erzberger, the CJEU replied to the preliminary question in the case Pöpperl ${ }^{22}$ that a Member State infringes Article 45 TFEU if a civil servant who decides to leave for work in another Member State is retroactively deprived of the pension benefits reserved to civil servants. At the opposite end of the set of similar cases of leav-

22 CJEU C-187/15 Joachim Pöpperl, EU:C:2016:550. 
ing for work in another country is the CJEU judgment in the Graf case from the year $2000^{23}$, which some of the parties to the Erzberger case also invoked. In that case, the CJEU found that the complainant was not prevented from moving freely to work in another Member State by being refused an unemployment benefit by his home State, because the link between that refusal and the freedom to migrate to work was regarded as ,too indirect and uncertain“. It is possible to ask whether the situation of a TUI AG employee in Germany who, by transferring within the TUI group to work in another Member State, loses the right to vote and to be elected to the Supervisory Board, is closer to Mr Pöppel's situation or Mr Graf's situation. If we find the similarity with Pöpperl, the only conclusion would be that there is an obstacle to the free movement of workers, which, if not justified and proportionate, would be contrary to Article 45 TFEU. Adhering to Graf on the other hand, there will be no obstacles to free movement, as the freedom of TUI AG employees in Germany to migrate will not be limited.

The Commission has fundamentally departed from its earlier written statement in the same case and at the oral hearing it argued that the obstacle to the free movement of TUI AG workers in Germany was present, but such a restriction could be justified, because the employee participation was ,an important public policy objective“". ${ }^{24}$ The Advocate General advocated an opposite view by concluding that EU law cannot guarantee the migrant worker the complete neutrality of his move to another member country in terms of working conditions, social security benefits etc. The advantages enjoyed by the employee under the law of one Member State simply do not migrate with him if he chooses to be subject to the legislation of another Member State. (para 69). Until there is no harmonized EU legislation in matters of co-determination, the act of labor migration brings the migrating worker to a different legal regime, within which he cannot be discriminated against, but in which he may lose some of the benefits enjoyed in his home country. At the same time, the Advocate General rejected the parallel with the Graf judgment, because ,the loss of the right to vote and to stand for election as representatives of employees within the supervisory board of the company and, where appropriate, the loss of the seat on that board where the employee is transferred to another Member State cannot in my view be regarded as too indirect and uncertain..." (footnote 59). Anyway, such an argument was not necessary if it were enough to assert that under EU law the migrant worker cannot claim the social and employment neutrality of his transfer between Member States.

Nevertheless, the Advocate General offered also the solution in the event that the CJEU would have shared the Commission's view and found the existence

\footnotetext{
CJEU C-190/98 Volker Graf, EU:C:2000:49.

24 Commission, Statement 17/141 from January 24, 2017.
} 
of an obstacle to free movement. He therefore proposed a justifiable exemption from the ban to limit the free movement that would be ,justified by the objective of ensuring employee participation within the company, in accordance with the national social, economic and cultural particularities." (para 106). He did not go that far as some of the parties recommended and did not suggest to recognize as an acceptable justification either the diversity of national social models for employee participation or the straight reference to Article 4 (2) TEU, according to which national differences in the application of the rules of co-determination would be the component of Member States' national identity respected by EU law. In the end, the CJEU did not need any of such justifications because it very briefly adhered to the line of argument that EU law (in particular Article 45 TFEU) cannot guarantee the neutrality of transfer of a worker to another Member State in terms of the conditions of his work and social advantages. (paras 34-35). The Article 45 TFEU is therefore not infringed even when a TUI AG employee is transferred from Germany to work in another EU Member State and EU law does not prevent Member States from laying down limits on the application of their co-determination rules. (paras 36-39).

The CJEU chose once again the easiest route to the target and avoided dealing with interesting, but complicated questions burdened with risky implications. It did not specify any criteria of (in)direct or (un)certain influence of a State measure over the choice to stay or migrate and did not open the door to attempts of challenging different types of would-be "limitations" of movement resulting from differences in national employment rules. It did not discuss the possibility to either easily justify an obstacle to the free movement by differences between national social systems, or recognize the rules of co-determination as part of a national identity. If that were the case, Pandora box would have been opened and an avalanche of creative justification for all possible national exceptions from EU internal market rules might have followed. Despite the above-mentioned unresolved aspects of the problem, the CJEU sent to national legislators and multinational employers a soothing message: limitation of the application of national rules on co-determination to national territory is not a breach of EU law (certainly in cases where "foreign" employees belong to a "foreign" entity within a group).

\section{CONCLUSION}

In the Erzberger judgment, the CJEU undoubtedly sought to minimize the practical implications and consequent complications that the case with far-reaching legal and non-legal connotations could have caused. Despite certain doubts and lack of answers mentioned in this text, it was basically a decision that avoided the legal confusion which would have arisen if a contradiction were 
found between German rules of co-determination and EU law. The ruling also prevented further dismantling of the achievements of a specific model of the welfare state, which should fundamentally be shaped by the debate and consensus of politically relevant forces within the German society, not by the verdicts of a supranational judicial authority. At the same time, the CJEU, by briefness of its reasoning (42 paragraphs only), did not allow to question the degree of integration of the EU internal market through the absolutization of certain differences between Member States.

The fact that the CJEU left some questions to which we would like to know the answer without a solution means, among other things, that the door remained open to further development, whether at the national level (change in the application of German co-determination rules according to the Scandinavian model) or at the EU one (agreement on the harmonization of certain rules on cross-border co-determination). So the ball is now on the politicians' and their voters-employees' side of the playground. If they really worry that employees of multinational companies with headquarters in Germany are not able to vote and be elected to supervisory boards if they are not employed on the territory of Germany, they have to find a political way to change national laws or to harmonize them at EU level.

If many people nowadays complain that the courts are narrowing the room that should remain at the disposal of legislators, the CJEU did not do anything similar in its Erzberger decision. The remaining uncertainty about cross-border application of the rules of co-determination is surely worth it. Whoever cannot stand this uncertainty should, in order to be on the safe side, allow all employees of his foreign establishments to vote and be elected to the governing bodies of the company's headquarters.

\section{LITERATURE}

1. Berger, B., Vaccarino, E.: Codetermination in Germany - a role model for the UK and the US? The Bruegel Newsletter, Oct 13, 2016. [http://bruegel.org/2016/10/ codetermination-in-germany-a-role-model-for-the-uk-and-the-us/], accessed on 11/07/2018.

2. Hellwig, H.J.: German Corporate Co-Determination of Employees and EU Law. University of Oxford, Faculty of Law Business Law Blog, 24 February 2017. [https://www.law.ox.ac.uk/business-law-blog/blog/2017/02/german-corporate-co-determination-employees-and-eu-law], accessed on 11/07/2018.

3. Höpner, M. Weiss, M.: Co-determination Under Threat: Blocking Social Europe. Social Europe. 12 January 2017, [https://www.socialeurope.eu/co-determination-threat-blocking-social-europe], accessed on 11/07/2018. 
4. Keijzer, T., Oost, O., van Ginneken, M.: The ECJ Erzberger Case: An Analysis of German Co-Determination and EU Law. European Company Law journal, Vol. 14, No. 6 (2017).

5. Koldinská, K., Tomeš, I. Křepelka, F.: Sociální právo EU. Praha: Wolters Kluwer 2018.

6. Krause, R.: Acid Test ECJ. The EU Commission's opinion on the TUI Case - A critical commentary. Hans-Böckler-Stiftung Co-Determination Report No 23., August 2016.

7. Mulder, J.: The Law Concenring the Election of Employees' Representatives in Company Bodies. Report in light of the CJEU case Konrad Erzberger $v$ TUI AG C-566/15. Hans-Böckler-Stiftung Co-Determination Report No. 29, January 2017.

8. Seidl-Hohenveldern, I.: Mezinárodní právo veřejné. 2. vydání, Praha: ASPI Publishing, 2001.

9. Wisskirchen, G. et al.: Employee representation and co-determination rights in Europe. Labour and Employee Benefits Practical Law Company Handbook 2010/11 Vol. 1. 